\title{
Recent Extinct Land Snails (Euconulidae) from the Gambier Islands with Remarkable Apertural Barriers ${ }^{1}$
}

\author{
Philippe Bouchet and Abmed Abdou ${ }^{2}$
}

\begin{abstract}
Based on study of material collected in the Gambier Islands (eastern Polynesia) by the 1934 Mangarevan Expedition and in 1997, two endemic species of Euconulidae are shown to exhibit apertural barriers unlike those of any other Pacific island limacoids, both in their ontogeny and development. The barriers are fully developed only in juveniles and subadults and are resorbed in full-grown individuals. Aukena, hitherto considered a subgenus of the HawaiianPolynesian genus Hiona, is elevated to genus rank. Aukena endodonta, n. sp., with six apertural barriers (one columellar, three parietal, two palatal), is described, and $A$. tridentata (Baker, 1940) is redescribed. The natural environment of the Gambier Islands had already been severely altered by 1934, and the two endemic species of Aukena are considered extinct. One other endemic euconulid without apertural barriers, Philonesia mangarevae Baker, 1940, survives in a small patch of native forest at the base of Mount Mokoto.
\end{abstract}

East of the Tuamotus, the easternmost high islands of Polynesia are stretched over immense expanses of deep ocean, with concomitant high levels of biological endemism. The Gambiers are such an isolated group of small, volcanic islands, 6 myr old (Bellon 1974). Their total land area does not exceed $26 \mathrm{~km}^{2}$, of which Mangareva, with a maximum elevation of $440 \mathrm{~m}$, occupies $60 \%$. The Bishop Museum Mangarevan Expedition visited the island group in 1934 and made extensive mollusk collections (Cooke 1935), revealing an extraordinary diversity of at least 34 native species of land snails, with an $85 \%$ level of endemism (Solem 1983). Based on the material of the Mangarevan Expedition, Baker (1940) described two new, endemic species of Euconulidae (Gastropoda, Stylommatophora). Philonesia mangarevae Baker, 1940 , was collected alive in a small patch of native forest remaining at the base of the cliff of Mount Mokoto, and Hiona? (Aukena) tri-

\footnotetext{
${ }^{1}$ Manuscript accepted 4 May 2000.

${ }^{2}$ Museum National d'Histoire Naturelle, 55 rue Buffon, 75005 Paris, France.
}

Pacific Science (2001), vol. 55, no. 2:121-127

(C) 2001 by University of Hawai'i Press.

All rights reserved dentata Baker, 1940, was described based on two "subfossil" shells. Because of the levels of threats to, and extinction of, Pacific island land snails (e.g., Cowie 1992, Hadfield et al. 1993, Coote et al. 1999), the Gambiers were revisited in 1997 in an attempt to document the conservation status of their native mollusk fauna. The stations of the Mangarevan Expedition were resurveyed and new stations were collected. Overall, a massive extinction of the endemic biota has taken place (Bouchet 1998), and the purpose of this paper is to report on a new, extinct species of Euconulidae with a remarkable development of apertural barriers. The higher classification follows Baker (1938, 1940) and Hausdorf (1998).

\section{MATERIALS AND METHODS}

Fieldwork was carried out in the Gambier Islands by P.B. in September 1997. Twentyfour stations were sampled and more than 50,000 shells of native and introduced snails were collected. However, only two stations yielded Euconulidae of the genus Aukena, represented by 10 specimens:

(1) Gambier Islands, Mangareva Island, Ganhutu, ca. 1.5-2 $\mathrm{m}$ above sea level, sandy soil with grass, planted coconuts, 17 September 1997. Coordinates: $23^{\circ} 04.6^{\prime} \mathrm{S}$, $134^{\circ} 56.6^{\prime} \mathrm{W}$. Numerous Endodontidae and 
Helicinidae. Euconulidae present: Aukena tridentata (7). This locality is identical to or very near station 277 of the Mangarevan Expedition.

(2) Gambier Islands, Aukena Island, north side of central isthmus, ca. 7-8 $\mathrm{m}$ above sea level, sandy soil, recently cleared for cultivation, 18 September 1998. Coordinates: $23^{\circ} 07.6^{\prime} \mathrm{S}, 134^{\circ} 54.0^{\prime} \mathrm{W}$. Numerous Endodontidae. Euconulidae present: Aukena tridentata (1), A. endodonta, n. sp. (2).

Subsequently, the material collected by the 1934 Mangarevan Expedition was examined during a visit to the Bishop Museum (вРвм) by P.B. in September 1997. Euconulidae is represented by four specimens: Gambier Islands, Mangareva Island, Ganhutu: Aukena endodonta, n. sp. (1, врвм 138963 as Microcystis "juv."); and Gambier Islands, Aukena Island: Aukena tridentata (2, syntypes, врвм 138682; 1, врвм 138697 as Microcystis "fossil").

In his monumental, and unsurpassed, revision of the helicarionoid snails of the Pacific Islands, Baker (1938:5-6) described shells of these animals by using a specific methodology and terminology, which is followed here; to facilitate comparison with Baker's results, we also use the same abbreviations. The height (alt.) of the shell is the greatest dimension parallel to the shell axis; the major diameter (maj. diam.) is the maximum width at right angles to that axis; the minor diameter (min. diam.) is that at $90^{\circ}$ to the major; the height of the aperture (alt. ap.) is taken from its projection on a vertical plane and is measured parallel to the shell axis. In the tables indices of the last three dimensions are expressed as percentages of the first (alt.) and precede the actual dimensions in millimeters, which are included in parentheses. The diameter of the aperture (diam. ap.) is measured at right angles to the shell axis from the center of the columellar edge; its index is a percentage of the aperture height. The total number of whorls is abbreviated whs. Obliquity of the aperture is expressed in terms of the angle between the shell axis and a line connecting the top of the columella with the shell periphery. Obliquity of the peristome is the angle between the plane of the aperture and the shell axis.

\section{SYSTEMATICS}

Gastropoda, Euthyneura, Stylommatophora Superfamily Gastrodontoidea Tryon, 1866

Family Euconulidae H. B. Baker, 1928

Subfamily Microcystinae Thiele, 1931

Tribe Philonesinni H. B. Baker, 1938

Genus Aukena H. B. Baker, 1940

Type species: Hiona? (Aukena) tridentata

H. B. Baker, 1940, by original designation.

Baker (1940) presented a combined (sub)generic and specific description. With the discovery of a second species in the genus, we propose a separate generic diagnosis.

Diagnosis: A group of Microcystinae with small, globular shells, in which the aperture of the shell of juveniles has parietal lamellae and palatal teeth; both juveniles and adults have a strong columellar bulge. Anatomy unknown.

REMARKs: Aukena differs from other Philonesiini in the development of the apertural barriers. Some Microcystini, such as Lamprocystis ensifera (Mousson, 1869) from Tonga, may have apertural barriers in the form of a columellar tooth and palatal lamellae, but they do not have parietal lamellae or teeth. Furthermore, whereas in Aukena the apertural barriers are most developed in the juveniles and disappear in the adults, in Lamprocystis the apertural barriers become more complex as the animals grow.

Aukena tridentata (H. B. Baker, 1940)

Figures 1-7

Hiona? (Aukena) tridentata H. B. Baker, 1940:177, pl. 34, figs. 10-15.

MATERIAL EXAMined: Aukena: lectotype (because Baker based his description on the larger of the two syntypes, this specimen is here designated as lectotype) and paralectotype (врвм 138682); 1 (врвм 138697; last whorl severely chipped, no measurements taken) Mangarevan Expedition; 1 (MNHN, broken during mounting). Ganhutu: 6, all juveniles (MNHN). 

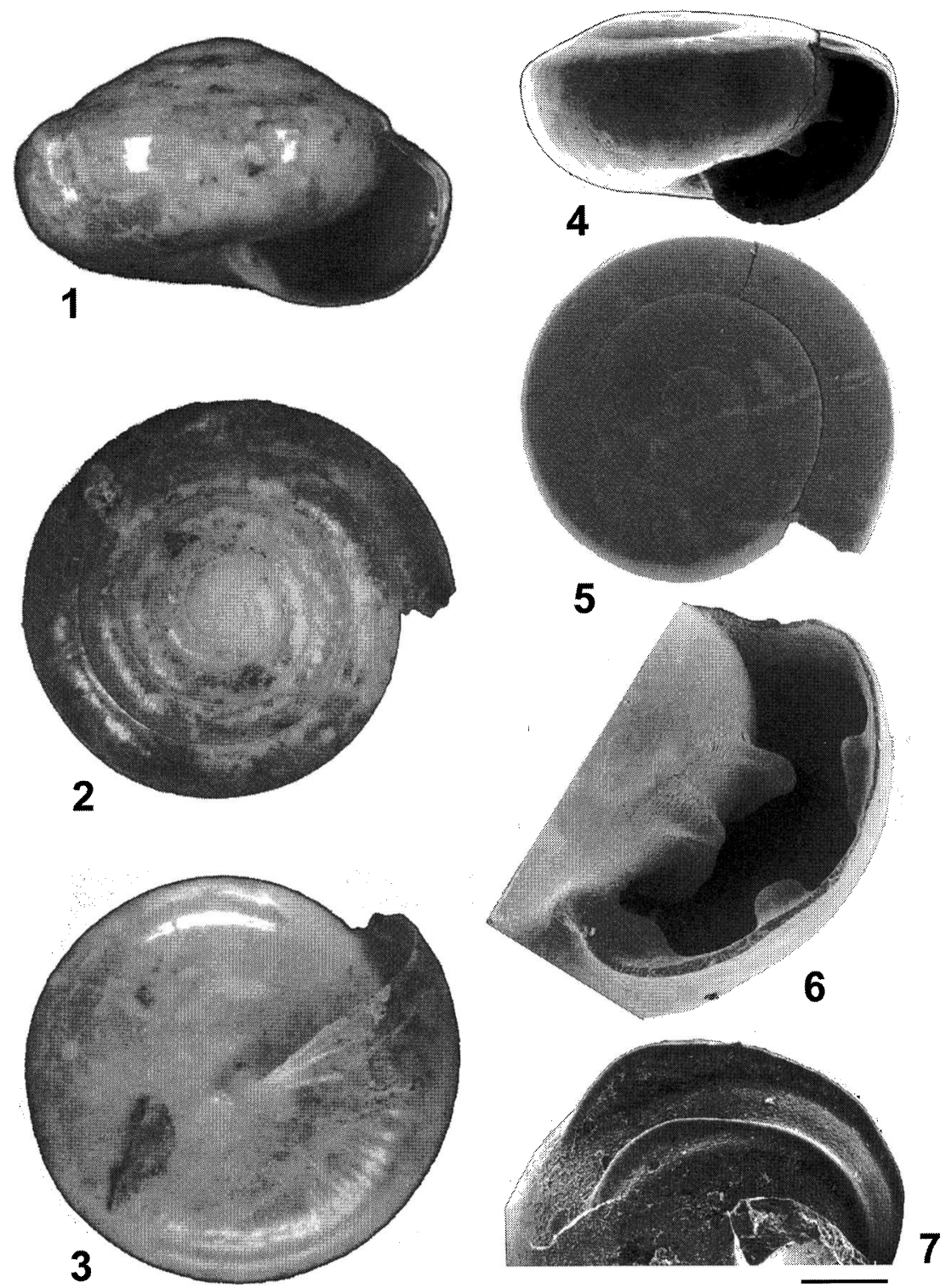

Figures 1-7. Aukena tridentata (Baker, 1940), Gambier Islands, French Polynesia. 1-3, lectotype, врвм 138697, diameter $5.52 \mathrm{~mm}$, Mangarevan Expedition 1934, Aukena Island. 4-5, juvenile, MNHN, diameter $2.16 \mathrm{~mm}$, collected 1997 on Mangareva Island. 6, apertural barriers of specimen of diameter $1.84 \mathrm{~mm}$. 7, same specimen, detail of parietal lamellae, scale line $0.2 \mathrm{~mm}$.

DESCRIPTION: Shell of lectotype globular (but sharply angulated above periphery in juveniles), moderately angulated on fourth whorl and weakly so at end of fifth, with broad, shallow foveola. Apical whorls almost flat, gradually becoming more convex, suture impressed. Protoconch/teleoconch transition indistinct, total number of whorls 5, sculptured by fine incremental lines, most distinct on shell base, and extremely fine spiral lines 
TABLE 1

Dimensions of Specimens of Aukena tridentata

\begin{tabular}{lcccclc}
\hline \hline Alt. & Maj. Diam. & Min. Diam. & Alt. Ap. & Diam. Ap. & Whs. & Specimen \\
\hline 3.35 & $165(5.52)$ & $153(5.14)$ & $61(2.03)$ & $133(2.70)$ & $5+$ & lectotype \\
3.10 & $158(4.90)$ & $149(4.62)$ & $67(2.09)$ & $118(2.47)$ & 4.7 & paralectotype \\
1.12 & $164(1.84)$ & $150(1.68)$ & $78(0.88)$ & $104(0.92)$ & 1.8 & \\
1.06 & $204(2.16)$ & $174(1.84)$ & $91(0.96)$ & $106(1.12)$ & 2.4 & \\
1.04 & $161(1.68)$ & $146(1.52)$ & $85(0.88)$ & $100(0.88)$ & 1.8 & \\
0.96 & $171(1.64)$ & $158(1.52)$ & $83(0.80)$ & $95(0.76)$ & 1.7 & \\
0.92 & $174(1.60)$ & $156(1.44)$ & $87(0.80)$ & $100(0.80)$ & 1.75 & \\
0.88 & $182(1.60)$ & $164(1.44)$ & $82(0.72)$ & $100(0.72)$ & 1.7 & \\
\hline
\end{tabular}

only seen with very oblique light. Aperture lunate, about $70^{\circ}$ to shell axis, peristome about $10^{\circ}$ to shell axis. Columella heavy, with bulge in basal angle; no other apertural barriers in lectotype. Color of shell opaque white.

Paralectotype with 4.7 whorls, with one elevated parietal lamella that extends for some distance into aperture, and one low, short palatal tooth situated some distance into aperture and facing parietal lamella. Farther into aperture, about 0.2 whorl from peristome, a second low palatal bulge, elongated radially.

Juveniles with 1.8 whorls, with two elevated parietal lamellae that extend for some distance into aperture, and two low, short palatal teeth: adaxial one approximately facing the adaxial parietal lamella, and abaxial one slightly above abaxial parietal lamella (parietal lamellae lacking in one specimen).

Dimensions are given in Table 1.

REMARKS: With two distinct parietal lamellae and two palatal teeth, the additional juveniles collected in 1997 show a more complex development of apertural barriers than in the subadult paralectotype. They have also helped to draw our attention to the second palatal bulge of the paralectotype, situated deep inside the aperture, which had escaped Baker's attention. Thus, the syntype that inspired Baker with the specific epithet tridentata has four (one columellar, one parietal, two palatal), rather than three apertural barriers!

\section{Aukena endodonta Bouchet \& Abdou, n. sp.}

Figures 8-11

TYPE MATERIAL: Aukena, central isthmus, $23^{\circ} 07.6^{\prime} \mathrm{S}, 134^{\circ} 54.0^{\prime} \mathrm{W}$ : holotype and one paratype (мNHN). Ganhutu: 1 paratype (вРвм 138963).

DESCRIPTION: Shell globular, with domeshaped spire, markedly angulated above periphery when young but becoming more evenly rounded by fourth whorl, with basal foveola broad and quite deep. Exposed part of early whorls rather convex, suture impressed, last two adult whorls with shallow subsutural ramp, suture adpressed. Protoconch/teleoconch transition indistinct, total number of whorls 5 , sculptured by very fine incremental lines, most distinct subsuturally, base sculptured by shallow, indistinct, spiral grooves. Aperture lunate, about $90^{\circ}$ to shell axis, peristome about $15^{\circ}$ to shell axis, with an indistinct basal varix a little behind the aperture edge. Columella very heavy, with solid bulge in basal angle; no other apertural barriers in holotype. Color of shell opaque white.

Larger paratype (MNHN) with 4.5 whorls, outer shell layer etched; columellar pillar very strongly projecting abaxially; three high parietal lamellae, adaxial one very thick, abaxial one a narrow ridge; interspace between adaxial and central lamellae about twice as broad as interspace between central and abaxial lamellae; two high palatal lamellae of about equal strength, projecting between interspaces of parietal lamellae. 

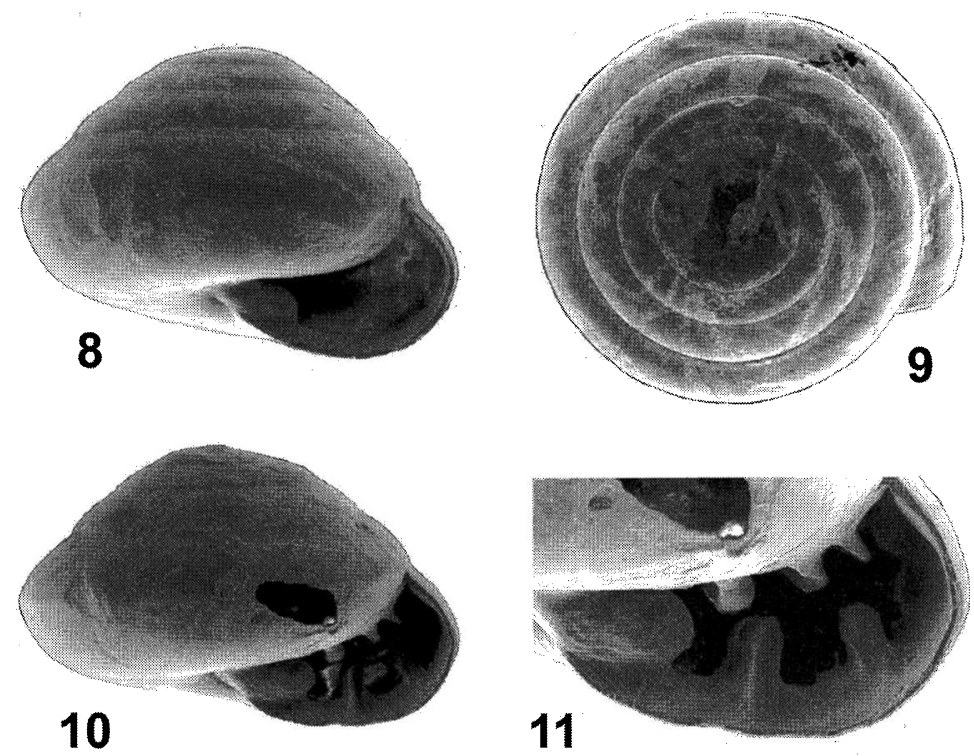

Figures 8-11. Aukena endodonta, n. sp., Aukena Island, Gambier Islands, French Polynesia. 8-9, holotype, MNHN, diameter $3.4 \mathrm{~mm}$. 10-11, paratype, MNHN, diameter $3.16 \mathrm{~mm}$.

Smaller paratype (врвм) with 3.5 ? whorls (apical whorls broken, but fragment still in place), strongly angulated; columellar pillar very strong, bifid; adaxial parietal lamella not developed; other parietal and palatal lamellae as in larger paratype.

Dimensions are given in Table 2.

eтYMology: Greek endos, inside, and odous (plural odonta), tooth, with reference to the complex apertural barriers of the juvenile and subadult shells.

reMARKS: Aukena endodonta differs from A. tridentata by its smaller adult size (specimens with five whorls measure 3.4 versus $5.5 \mathrm{~mm}$ in maximum diameter, respectively), higher spire (maj. diam./alt. of the two largest specimens of $A$. endodonta 1.52 versus 1.56 in
A. tridentata), and more solid shell, but above all by the development of the apertural barriers, which are not only more numerous in $A$. endodonta, but also higher and extend into the aperture a longer distance.

\section{DISCUSSION}

\section{Aukena as a Genus}

Baker (1940:177) treated Aukena as a subgenus of Hiona Cooke [in Baker], 1940 (type species by original designation Microcystis platyla Ancey, 1889, from O‘ahu, Hawaiian Islands). In Hiona (Hiona), he placed Hawaiian species, but the species from the Marquesas, Society Islands, and Rapa were classified in

TABLE 2

Dimensions of Specimens of Aukena endodonta

\begin{tabular}{lllllll}
\hline \hline Alt. & Maj. Diam. & Min. Diam. & Alt. Ap. & Diam. Ap. & Whs. & Specimen \\
\hline 2.32 & $146(3.4)$ & $141(3.28)$ & $45(1.04)$ & $154(1.60)$ & 5 & holotype \\
2.0 & $158(3.16)$ & $170(3.04)$ & $52(1.04)$ & $138(1.44)$ & 4.5 & paratype MNHN \\
1.3 & $172(2.24)$ & $163(2.12)$ & $73(0.96)$ & $116(1.12)$ & 3.5 & paratype BPBM \\
\hline
\end{tabular}


Hiona (Insulorbis), H. (Neutra), and H. (Opara), respectively, all described as new by Baker. Of Aukena, Baker wrote: "The addition of parietal and basal [palatal] lamellae to the shell certainly warrants generic separation, but I do not like to erect a new genus on the basis of a single specimen." Because of the considerable convergence that takes place in shell characters of the limacoids, only anatomical characters would unambiguously permit an evaluation of the status of Aukena, but, like Baker, we do not have access to this character set. Likewise, the euconulids of the nearby Pitcairn Islands are poorly known. Preece (1995:302, figs. 9A-C) reported from Pitcairn as Hiona (Minorbis) verticillata (Pease, 1868) three historical shells of a microcystine with thickened columellar bulge, and from Henderson as Hiona sp. one fragmentary specimen without apertural barrier (Preece 1998). The discovery in the Gambier Islands of an additional species of Euconulidae with apertural barriers even stronger than in $H$. tridentata reinforces the view that a separate radiation of Hiona s.l. has taken place in that island group. Admittedly, treating Aukena as a subgenus of Hiona could equally serve to flag the Gambiers radiation as separate from that of other island groups. Because a phylogenetic analysis based on anatomical characters will never be possible since the species are extinct, our decision to rank Aukena as a genus is admittedly subjective and not falsifiable.

\section{The Function of Apertural Barriers}

It is remarkable that all four native families of Stylommatophora historically living on the Gambiers (Achatinellidae, Endodontidae, Vertiginidae, and Euconulidae) had a majority of species with apertural barriers. However, although the presence of apertural barriers is the normal condition in Achatinellidae, Endodontidae, and Vertiginidae, this condition is exceptional in the Euconulidae. It is thus the more remarkable that of three species of Euconulidae historically living on the Gambiers, two have apertural barriers.

Although the development of a columellar fold is a recurrent tendency thoughout the Microcystinae, the apertural barriers of $A u$ - kena endodonta are by far the most complex of all Pacific Islands species of Euconulidae. Baker (1940:164) noted that "complications of the shell are usually strongest in the younger shells and tend to disappear in the older specimens" and speculated that "possibly in these snails with continuous growth, the armature of the aperture and last whorl may offer protection against enemies, but restrict, to some degree, the functioning of the ripe genitalia." Solem (1972) suggested that the apertural barriers provide protection from arthropod micropredators, a hypothesis rejected by Tillier (1989:6), who suggested that the main function of apertural barriers in small shells is to reduce the evaporation surface of the retracted snail. In fact, both factors may operate. Juveniles have a larger body surface per volume than adults, and juvenile limacoids are capable of retracting more completely into the shell; apertural barriers would serve both to limit the evaporation surface and to fence the aperture from predators. Conversely, adult limacoids having a smaller body surface would need to limit their evaporation surface less than juveniles; also adult limacoids frequently cannot retract completely into the shell, so that apertural barriers would not be effective to fence the aperture and perhaps the adult snails of $\mathrm{Au}$ kena had other defense mechanisms in the form of mantle gland or caudal gland secretions. Because the natural biota of the Gambiers has been so profoundly modified, these hypotheses cannot be tested.

\section{Evidence That the Species of Aukena Are Extinct}

When the Mangarevan Expedition visited the Gambiers in 1934 they found only a small patch of native forest remaining at the base of the cliff of Mount Mokoto. The narrative of the expedition makes it clear that considerable effort was spent by skilled collectors to find living specimens of the native snails, but only empty shells of most species were found (Cooke 1935). When the Gambiers were revisited in 1997, the small patch of native forest at the base of Mount Mokoto was still there and was still inhabited by the endemic Philonesia mangarevae. However, the rest of 
the islands is completely devoid of natural vegetation and is either covered with "grass" (Miscantbus floridulus) or replanted with exotics (mostly Casuarina equisetifolia and $\mathrm{Al}$ bizia lebbeck). Such habitats harbor introduced species of land snails, but no endemic/native species. The islands of Mangareva and $\mathrm{Au}-$ kena are rugged, and the two localities where the shells of Aukena were collected in 1934 and 1997 are small coastal plains that are now (and presumably were in 1934) completely modified for small-scale subsistence agriculture. The specimens were found in superficial sandy soil with shell accumulations.

The overall change in the land snail fauna of the Gambiers will be discussed in another paper, but we take as evidence that the species of Aukena are extinct the fact that only empty shells have been found despite two independent, focused surveys, and the fact that the native vegetation has disappeared over $99 \%$ of the islands' area.

\section{ACKNOWLEDGMENTS}

P.B. is most grateful to Bruno Schmidt of Rikitea, Mangareva, for his extensive help during the 1997 fieldwork and for sharing his knowledge on the recent history of his native island, and to Robert Cowie for hospitality, discussions, and access to the collections of the Mangarevan Expedition during his visit to the Bishop Museum. Illustrations were prepared by Philippe Maestrati (MNHN) and Michèle Grasset (cime, Paris).

\section{Literature Cited}

Baker, H. B. 1938. Zonitid land snails from Pacific Islands. Part 1. Southern genera of Microcystinae. Bernice P. Bishop Mus. Bull. 158:1-102, pls. 1-20.

1940. Zonitid land snails from Pacific

Islands. Part 2. Hawaiian genera of Microcystinae. Bernice P. Bishop Mus. Bull. 165:105-201, pls. 21-42.

Bellon, H. 1974. Histoire géochronométrique des iles Gambier. In Gambier. Cah. Pac. 1 (18): 245-251.

Bouchet, P. 1998. Mangareva: Splendor and decline of a Pacific island land snail fauna. Page 39 in R. Bieler and P. M. Mikkelsen, eds. Abstracts, World Congress of Malacology, Washington, D.C.

Cooke, C. M. 1935. Report of C. Montague Cooke, Jr., malacologist and leader, Mangarevan expedition. Bernice P. Bishop Mus. Bull. 133:36-56.

Coote, T., E. Loeve, J.-Y. Meyer, and D. Clarke. 1999. Extant populations of endemic partulids on Tahiti, French Polynesia. Oryx 33:215-222.

Cowie, R. H. 1992. Evolution and extinction of Partulidae, endemic Pacific island land snails. Philos. Trans. R. Soc. Lond. B Biol. Sci. 335:167-191.

Hadfield, M. G., S. E. Miller, and A. H. Carwile. 1993. The decimation of endemic Hawaiian tree snails by alien predators. Am. Zool. 33:610-622.

Hausdorf, B. 1998. Phylogeny of the Limacoidea sensu lato (Gastropoda: Stylommatophora). J. Molluscan Stud. 64:35-66.

Preece, R. C. 1995. Systematic review of the land snails of the Pitcairn Islands. Biol. J. Linn. Soc. 56:273-307.

- 1998. Impact of early Polynesian occupation on the land snail fauna of Henderson Island, Pitcairn Group (South Pacific). Philos. Trans. R. Soc. Lond. B Biol. Sci. 353:347-368.

Solem, A. 1972. Microarmature and barriers in the aperture of land snails. Veliger 15 (2): 81-87.

. 1983. Endodontoid land snails from Pacific Islands (Mollusca: Pulmonata: Sigmurethra). Part 2. Families Punctidae and Charopidae. Zoogeography. Field Museum of Natural History, Chicago. ix +336 pp.

Tillier, S. 1989. Comparative morphology, phylogeny and classification of land snails and slugs (Gastropoda: Pulmonata: Stylommatophora). Malacologia 30 (1-2): 1303. 